\title{
Implementation of Criminal Provisions About Doubling the Price of Hand Sanitizer During the Covid-19 Disaster
}

\author{
Nurhidayat $^{1}$, Azis Budianto $^{2}$ \\ \{hidayat5588@gmail.com¹, azis_budianto@borobudur.ac.id² \\ Universitas Borobudur, Jakarta, Indonesia ${ }^{1,2}$
}

\begin{abstract}
Doubling the price of hand sanitizers amid the COVID-19 emergency is a crime beyond human reason. This study examines the implementation of the crime against the corruption of doubling the cost of hand sanitizers during the COVID-19 disaster. The method used is an empirical approach by directly interviewing informants, which is then analyzed by qualitative methods. According to the findings of the research, the crime of double the price of hand sanitizers can be penalized under Laws No. 7 of 2014 about trade and Law No. 8 of 1999 concerned consumer protection, with a maximum penalty of five years in jail or a fine of two billion dollars.
\end{abstract}

Keywords: Implementation; Multiplication; Hand Sanitizer; Covid-19

\section{Introduction}

Indonesian people are currently afraid of contracting the virus, which is known to have originated in China, precisely in Wuhan, Hubei province, China [1]. The virus was first discovered in November 2019, where at one integrated hospital in China, there was one patient from the city of Wuhan who experienced symptoms resembling pneumonia [2]. Medical personnel at that time could not conclude that the patient had contracted the virus or was purely from a congenital illness. In December 2019, not long after, around 60 residents of the city of Wuhan experiencing the same symptoms as the first patient. Local authorities investigated and discovered that a new form of virus known as 2019 - Novel Corona Virus (2019-nCoV), also known as Corona Virus Disease - 2019 (Covid-19), had emerged, with symptoms similar to those of the Severe Acute Respiratory Syndrome virus [3].

The covid-19 virus is a virus that attacks the human body through the consumption of food derived from wild animals such as rats, bats, and primates. From 1960 to 2019, it turned out that $\mathrm{nCoV}$ had many different genera, Alpha Corona Virus, Beta Corona Virus, Gamma Corona Virus, and Delta Corona Virus are only a few examples. Some of the virus genera that can only attack the human body to result in death are the Alpha and Beta genus [4]. The covid19 virus itself is included in the beta genus because the virus will first infect animals and then infect the human body for the virus to develop. The COVID-19 virus, according to the World Health Organization (WHO), causes respiratory infections in humans ranging from the common cold to more serious diseases such as Middle East Respiratory Syndrome (MERS) 
and Severe Acute Respiratory Syndrome (SARS) with symptoms such as fever and respiratory problems. Cough, runny nose, sore throat, fatigue, and lethargy in carrying out daily activities for sufferers [5].

The Covid-19 virus that has entered the territory of Indonesia has made the Ministry of Health of the Republic of Indonesia (Kemenkes RI) seek to provide education to the Indonesian people about the virus by issuing several articles about the covid-19 virus, which explain that to find out how to transmit the covid-19 virus. Still under investigation. The health authorities in China suspect that the COVID-19 virus originated from the animal/fish market in Wuhan because many patients who contracted the COVID-19 virus were workers at the animal/fish market.

In March 2020, the results of its research showed that the covid-19 virus could not spread through air media because each virus has a mass/weight amount that causes the virus to be attracted by gravity. In March 2020, two Indonesian citizens (WNI) were positively infected with the Covid-19 virus due to physical contact with a foreign citizen (WNA) from Japan who was visiting the Indonesian citizen's house. The foreigner came from a Japanese country who lived in Malaysia. On his way to Indonesia, it turned out that the foreigner had taken feverreducing drugs so that the airport security equipment was not detected. The foreigner has contracted the COVID-19 virus from Malaysia, not after visiting Indonesia. From the incident until the end of March 2020, Indonesia has experienced a spike in the number of positive patients for the COVID-19 virus by approximately one thousand people in almost all provinces in Indonesia [6].

The high number of patients infected with the COVID-19 virus has made the Indonesian government appeal to the public not to panic and remain vigilant and comply with the policies that have been made, such as restricting restricted access, working from home, and studying from home. The Indonesian Ministry of Health made a guidebook for preventing and controlling the COVID-19 virus and published it to the public on March 16, 2020, to know the steps to avoid the Covid-19 virus. According to the Indonesian Ministry of Health, the following are some of the most effective preventive measures for the COVID-19 virus:

a. Perform hand hygiene using a hand sanitizer if the hands do not look dirty or wash hands with soap if the hands look dirty;

b. Avoid touching the nose, eyes, and mouth;

c. Apply the ethics of coughing or sneezing by covering the nose and mouth with the inner upper arm or tissue, then throw it in the trash;

d. Wear a medical mask if you have respiratory symptoms and perform hand hygiene after removing the cover;

e. Keep a distance (at least 1 meter) from people who experience symptoms of respiratory disorders.

From the several steps to prevent the covid-19 virus above, the author received information that there was a shortage of certain items such as masks and hand sanitizers amid the spread of the covid-19 virus in Indonesia. Irregularities regarding the scarcity of these goods have made the government and all state apparatus work together to investigate the causes of goods that are generally easy to obtain and become challenging to find. In addition to masks that are difficult to find, hand sanitizers, which have a significant role in keeping hands sterile, are also a problem. Besides being rare, some business actors deliberately make profits by doubling prices. Based on a statement expressed by WHO, hand sanitizer is the most effective tool used to clean hands while traveling. Hand sanitizer is a hand sanitizer that can reduce hand infections and kill microorganisms better than soap and water. People who know the current high price of hand sanitizers prefer to discourage buying them. 
Based on the field phenomenon that the author encountered, the author argues that the role of the Semarang city government, in this case, is very much needed to overcome business actors who took advantage during the COVID-19 virus disaster. Business actors who do not understand that doubling the price of hand sanitizers when there is a shortage of goods caused by a disaster will be threatened by the law. As the saying goes, Ubi Societas Ibi Ius, which means that where there is society, there is the law. Thus, the criminal law will apply to all activities that harm other people, take opportunities when disasters occur, and create panic. Based on the description above, the author will research the Implementation of Criminal Provisions About Doubling the Price of Hand Sanitizer During the Covid-19 Disaster.

\section{Methodology}

Field research or field research is the sort of research used. Field research is data collection that takes place in the field (usually primary information). Field research is a technique for determining exactly and realistically what is going on in a community. In addition, field research is also one of the data collection methods in qualitative research that does not require statistics, in-depth knowledge of the literature used, and specific abilities on the researcher's part. This research was conducted by going into the community and the competent authorities to obtain information and data about the phenomena that will be raised in this paper.

The type of approach used is an empirical approach. Empirical research examines legal data in the field, such as legal data in its application, legal phenomena in society, problems of legal efficacy and effectiveness, law enforcement and application, legal compliance, litigation and dispute resolution issues, and so on. The empirical approach is carried out by taking the object of study on certain legal aspects that have observed value to answer questions and hypotheses that have been arranged coherently by researching field data through observation.

Primary and secondary data sources were employed in this research. Primary data is data obtained by a researcher directly from the source without the intermediary of other parties (directly from the object), then collected and processed by themselves, as for one example that can be done to obtain primary data sources, namely by now interviewing the legal understanding of the community with the enactment of a rule through activities such as interviews and observations. Secondary data is used as the primary reference already available in the form of legislation, books, scientific journals, and other written sources. The author focuses on obtaining data sources in this study through interviews with business actors, especially those selling hand sanitizers at high prices and related agencies that deal with this. In addition, the authors also use data sources from relevant agencies and the internet as a review in finding the latest developments in the research that the authors do.

The data collection method used is the observation method. The surveyor observation method is a method that does not use a system or formed data (manipulation) but directly measures the existing facts to then see the correlations of different facts16. In this study, the author will make observations in one place and conduct interviews with the local community and related parties. The data obtained from the comments will be neatly arranged with a table arrangement so that the reader can understand the information that the author will convey in this paper. 


\section{Results and Discussion}

\subsection{Positive Indonesian Criminal Law Regulations Against the Crime of Doubling the Price of Important Goods in the Form of Hand Sanitizer}

The covid-19 virus, also known as SARS-CoV-2 (severe acute respiratory syndrome coronavirus 2) in technical terms, is a novel form of coronavirus that may infect people. This virus may infect anybody, including the elderly, adults, children, and even infants in their mothers' wombs. The COVID-19 virus, according to the World Health Organization, can cause respiratory tract infections in humans, ranging from coughs and colds to more serious diseases like Middle East Respiratory Syndrome (MERS) and Severe Acute Respiratory Syndrome (SARS) [7]. Because of the high death rate caused by the covid-19 virus, the Indonesian government, particularly the President of the Republic of Indonesia, has issued regulations to deal with the virus's spread, as set out in Presidential Decree Number 11 of 2020 concerning the Determination of Public Health Emergency Corona Virus Disease 2019, and Presidential Decree Number 12 of 2020 concerning the Determination of Non-Natural Disasters for the Spread of Corona Virus Disease [8].

As seen from the last few months, more than tens of thousands of people have been exposed to the Covid-19 virus. The ease with which the Covid-19 virus spreads is a significant factor in the increasing number of positive COVID-19 patients. The COVID-19 virus is disseminated mostly by droplets from the nose or mouth that are expelled when an infected person coughs, sneezes, or speaks. These splashes are rather heavy, travel a short distance, and settle rapidly. If a person breathes in the droplets of a COVID-19-infected individual, they can become infected with the virus. To anticipate the spread of the COVID-19 virus, the Ministry of Health of the Republic of Indonesia issued a policy related to public health protocols. The strategy is specified in the Minister of Health of the Republic of Indonesia's Decree Number HK.01.07/MENKES/382/2020 about Community Health Protocols in Public Places and Facilities in the Context of Corona Virus Disease Prevention and Control 2019. (Covid-19).

The goal of issuing this policy is to boost community efforts to prevent and manage COVID-19 in public spaces and facilities so that new epicenters/clusters do not emerge throughout the epidemic. As of June 15, 2020, the number of positive COVID-19 patients in Indonesia reached 78,572, with details increasing every day to 1,591 cases. Of the number of positive COVID-19 patients, 37,636 have been confirmed to have recovered, and 3,710 have been confirmed as having died. If you look at the data, many people still do not apply the recommended health protocols. According to the author, many people do not use health protocols because people do not know and cannot feel that the COVID-19 virus exists or is spread in the surrounding environment.

By following the health protocol guidelines set out in Chapter 2 (two) of the Minister of Health of the Republic of Indonesia's Decree Number HK.01.07/MENKES/382/2020 on Community Health Protocols in Public Places and Facilities in the Context of Corona Virus Disease Prevention and Control 2019. The contents of chapter 2 (two) are about how to prevent and avoid contracting the covid-19 virus as follows:

a. If you have to leave the house or deal with persons whose health condition is uncertain, use personal protection equipment such as a mask that covers your nose and mouth up to your chin (which may transmit COVID-19). If you're going to utilize a fabric mask, make it a 3-ply cloth mask. 
b. Clean hands regularly by washing hands with soap and running water or using an alcoholbased hand sanitizer. Always avoid touching your eyes, nose, and mouth with unclean hands (which may be contaminated with droplets containing the virus).

c. Avoid collecting droplets from individuals who are talking, coughing, or sneezing by keeping a distance of at least one meter from other people and avoiding crowds, crowds, and crowds. If keeping a safe distance is impractical, alternative administrative and technological engineering can be done. Limiting the number of members in a group, establishing timetables, and so on are examples of organizational engineering. Technical engineering can include, for example, partitioning, establishing access and exit routes, and so on.

d. Increase endurance by implementing a Clean and Healthy Lifestyle (PHBS), such as consuming balanced nutrition, physical activity for at least 30 minutes a day, adequate rest (at least 7 hours), and avoiding disease risk factors. People who have comorbidities/comorbidities/susceptible conditions such as diabetes, hypertension, pulmonary disorders, heart disorders, kidney disorders, immunocompromised conditions/autoimmune diseases, pregnancy, the elderly, children, etc., should be more careful in activities in public places and facilities.

Of the several preventive measures above, the authors highlight one of the health tools that can be used to prevent the spread of the COVID-19 virus, namely hand sanitizer. Hand sanitizer is a tool to clean hands without using running water, easy to use, practical, and has no side effects on users. The increase in people's purchasing power for hand sanitizers has resulted in hand sanitizers instantly becoming an essential item that must always be used when traveling. Unfortunately, the high price increases when people need hand sanitizers to protect themselves from the covid-19 virus, making people reluctant to buy them. The author argues that the rise in the price of hand sanitizers carried out by business actors is caused by the scarcity of these goods and indications of hoarding goods. Based on the author's observations, the sale of hand sanitizers from December to May experienced an increase in price by more than Rp. 50,000.00 (for a $100 \mathrm{ml}$ bottle), which was previously sold for Rp. 15,000.00 to Rp. $65,000.00$. Observations were made at several shops, pharmacies, mini markets in Semarang City, and online stores. The number of business actors who double the price of hand sanitizers tends to choose online media to sell and buy these goods.

Business actors deliberately multiply this because they see the potential to reap greater profits than usual. While people still want to purchase hand sanitizers at high prices, the selling price will remain high-high-priced sanitizer. Based on the observations mentioned above, the author will explain research results from law enforcement parties. The police, in this case, is in the jurisdiction of the Semarang City Police. The phenomenon that occurs in the field is a contemporary phenomenon, only for a moment and under certain circumstances. However, crime is not seen from the duration of the incident or under certain circumstances. Evil always arises when it has the intention and the opportunity to do so. Seeing the rise of business actors who doubled the price of hand sanitizers made the police feel confused because there is still a crime in a disaster like this. The Covid-19 virus disaster did not only occur in the city of Semarang, but the entire archipelago also felt the same way, even the world. The COVID-19 virus disaster has become the center of attention of the government and law enforcement to immediately address this so that it does not spread widely and control the panic that exists in the community.

Business actors who double the price of hand sanitizers can be subject to criminal sanctions using legal instruments, namely Law Number 7 of 2014 concerning Trade and Law Number 8 of 1999 concerning Consumer Protection. According to the police, the two laws are 
very effective in trapping crimes, such as doubling the price of hand sanitizers. Here, the author describes the articles regarding the corruption of doubling the cost of hand sanitizers regulated in each of these laws:

a. Law Number 7 of 2014 concerning Trade

Article 29, paragraph (1) states that "business actors are prohibited from storing necessities and important goods in a certain amount and time when there is a shortage of goods, price fluctuations, and trade traffic barriers." Referring to the article, business actors who commit crimes of doubling the price of imported goods can be punished.

If the two elements contained in the article are fulfilled, such as the scarcity of goods and price fluctuations, business actors can be punished. Hand sanitizer is currently a rare essential item due to the increasing purchasing power of the people. With the increase in people's purchasing power, business actors take the opportunity to reap profits at high prices that violate the provisions of the article.

b. Law Number 8 of 1999 concerning Consumer Protection.

Article 10 reads, "business actors in offering goods and services intended for trading are prohibited from offering, promoting, advertising or making statements that are not true or misleading regarding the price or tariff of goods and services; Use of an item and service; Conditions, dependents, guarantees, rights or compensation for goods and services; Discount offers or attractive prizes are offered; Danger of using goods and services."

Looking at the elements in the article, the business actor who multiplies the price violates the part in letter a, namely the price or tariff of an item and service. The tariffs traded are not following factory prices or prices that were previously widely circulated before the Covid-19 disaster occurred. From the police statement that the author has outlined, doubling the cost of hand sanitizers can be subject to criminal sanctions according to the applicable law.

According to the author, there were irregularities when the police determined that business actors who doubled the price of hand sanitizers could be punished. The discrepancy can be seen in the clause on essential goods/important goods in Article 29 paragraph (1) of Law Number 7 of 2014 concerning Trade. Considering that hand sanitizer is not a necessary item, there are legal problems that must be faced by law enforcement.

Seeds (rice seeds, corn, and soybeans), fertilizers, 3 (three) kilograms of LPG, plywood, cement, construction steel, and mild steel are among the essential goods listed in Article 2 paragraph (6) letter b of Presidential Regulation Number 59 of 2020 concerning Amendments to Presidential Regulation Number 71 of 2015 concerning Stipulation and Storage of Basic Needs and Important Goods.

Referring to one of Hogeraad's decisions on January 31, 1919, which understands that unlawful acts as known in Article 1365 of the Civil Code are interpreted as unlawful acts in written form and unwritten ones. In the principle of criminal law based on legality, namely, an act cannot be punished, except based on applicable legal provisions (positive direction).

The principle of legality is fundamental with one of its unique characteristics, namely the prohibition of using analogies, meaning that every law enforcement officer in terms of enforcing criminal law may not make interpretations that are outside the intent of the legislator or equate it with something that is not the same as others. This has become a debate that the meaning of essential goods can change according to circumstances.

Nevertheless, legal discovery can still be carried out if an unlawful nature exists in the violation. This can be interpreted by referring to the argument that an action can be called a crime if the heart of the action (Wesen) is "dem Wesen nach," in line with the intent of the intended criminal law provisions. In carrying out their duties in this case, the police use a 
systematic interpretation, namely an interpretation that focuses on the uniformity of other statutory provisions governing the same thing.

The author believes that the three theories of punishment that the author will describe strengthening that doubling the price of hand sanitizers can be punished with the legal instrument of Law Number 7 of 2014 concerning Trade. The three theories are absolute/retribution theory, objective/relative theory, and combined theory:

a. Absolute Theory / Retribution.

According to this theory, the punishment is imposed solely because of the person who has committed a crime or crime.[9] Immanuel Kant views crime as a "categories imperative," i.e., a person must be convicted by a judge because he has committed a crime so that the crime shows demand for justice. Doubling the price of hand sanitizer is a crime that does not have a solid legal basis in Law Number 7 of 2014 concerning Trade, but everyone who commits a crime must be punished.

b. Goal/Relative Theory

This theory views it as something that can be used to achieve utilization, both related to the guilty person and the outside world.[9] The benefits of being convicted of business actors who commit crimes will be felt by the public, making restless. The punishment of business actors who double the price of hand sanitizers impacts the normality of the selling value of hand sanitizers on the market.

c. Combined Theory

The purpose of the crime is always to avenge the mistakes of criminals. It is also intended to protect the community by creating order that the severity of the crime must not exceed the limits of fair retaliation. The combined theory emphasizes vengeance and protection. The purpose of retribution is that punishment must not exceed what is necessary and sufficient for maintaining social order. In contrast, protection, namely punishment, protects the order of society so that the suffering of being sentenced to a crime cannot be more severe than the act committed. The combined theory puts forward the side of justice for all parties, both business actors and the community, who feel aggrieved. Accepting the consequences of the actions taken cannot be avoided even if the sanctions are not heavier than usual. To provide a deterrent effect, it is deemed sufficient punishment is carried out.

\subsection{Implementation of Criminal Provisions Regarding Doubling the Price of Important Goods in the Form of Hand Sanitizer}

According to Moh. Mahfud MD[10], Legal politics refers to the legal policy of not enforcing laws in order to achieve governmental objectives. In this regard, Sunaryati Hartono[11] previously said that "law as a tool" indicates that legal politics is also a tool or methods and steps that the government may employ to construct a national legal system in order to fulfill the nation's objectives and the state's aims. According to Remmelink, criminal law is not an end in itself but aims to uphold the rule of law, protecting the legal community. The maintenance of social order is dependent mainly on coercion. Forced power is needed to bring order to the community. Many people still do not obey existing laws, such as crimes committed by business actors when the COVID-19 virus disaster occurred.

The crime of doubling the price of hand sanitizers carried out by business actors is based on the absence of a legal basis that regulates hand sanitizer items and the opportunity to reap higher profits that cannot be rejected. The author argues that it is normatively true, hand sanitizers do not have a legal basis. Still, crime cannot be left alone, considering that the law created order, benefit, and justice for the community. The author will present the results of the 
author's interviews with informants regarding the crime of doubling the price of hand sanitizers. According to the Head of the Trade Division, the crime of doubling the price of hand sanitizers said that the crime could not be punished. According to him, the increase in the price of hand sanitizers is only temporary. That is, it only occurs at certain times, such as during the COVID-19 pandemic. The price increase is not something that must be considered because the task of the trade office is only to supervise essential goods.

The main task of the trade office is to supervise essential goods such as sugar, rice, meat, etc., or virtual goods such as iron and nails. Primary goods are the center of attention because, during the COVID-19 pandemic, all essential goods are being hunted by the public. The central government instructs each region to pay attention to crucial goods and virtual goods used as income assistance for the basic needs of people in dire need and ensure that every community gets service. The absence of instructions from the central government has made the Semarang City trade office unable to monitor and take action against business actors who intentionally double the price of hand sanitizers. Suppose the hand sanitizer is an important item stated in Law Number 7 of 2014 concerning Trade. In that case, it will be dealt with per the provisions in Article 107, which reads: "Business actors who store necessities and important goods in quantity and time certain times when there is a shortage of goods, price fluctuations, and obstacles to the traffic of Trade in goods as referred to in Article 29 paragraph (1) shall be punished with imprisonment for a maximum of 5 (five) years or a fine of a maximum of Rp. 50,000,000,000.00 (fifty billion rupiah)."

It is unfortunate that hand sanitizers are not an essential category of goods and do not have a price limit or what is commonly referred to as the highest retail price, making the trade office unable to move to take action against business actors who are caught doubling the cost of hand sanitizers during the COVID-19 disaster. Hand sanitizers can be categorized as essential goods if the central government includes hand sanitizers in virtual goods following Presidential Regulation Number 59 of 2020 concerning Amendments to Presidential Regulation Number 71 of 2015 concerning Determination and Storage of Basic Needs and Important Goods. Article 2 paragraph (7), which reads "types of necessities and essential goods as referred to in paragraph (6) can be changed by a ministerial regulation based on a decision of a coordination meeting chaired by the coordinating minister who carries out government affairs in the economic sector, which the minister attends. / The head of a nonministerial government agency or an official appointed to represent and be given authority for and on behalf of the minister/head of a non-ministerial government agency".

Although the trade office cannot take action against these business actors, it is not only the trade office that takes preventive steps. The preventive effort carried out by the Semarang City trade office is to verbally appeal to business actors not to double the price of hand sanitizers but to sell them at average prices as before the Covid-19 virus spread to Indonesia. The trade office also participates in disseminating health protocols, especially in markets in Semarang City, so that people feel safe when making buying and selling transactions. Although hand sanitizers are not classified as essential goods, the act of doubling the price can be punished under Law Number 8 of 1999 concerning Consumer Protection. Not only based on price, if in the composition used to make hand sanitizers there are dangerous goods or making hand sanitizers without the rules causing harm to consumers, but they can also be punished.

Unfortunately, many business actors commit fraud by increasing prices and selling hand sanitizers of low quality during a disaster. Seeing this, the Ministry of Trade closed 169 online stores that were proven to sell hand sanitizers of low quality - not only closing the account but eliminating all history about accounts that are verified to sell hand sanitizers at high prices and low quality. Although many online stores have been closed due to fraud, conventional shops 
have done the same thing. Traditional stores can be subject to criminal sanctions following applicable regulations if it is proven that there are consumers who experience losses. The conventional shops are pharmacies, supermarkets, markets, and even grocery stores. Most of the traditional stores that do the act of increasing prices are supermarkets. At the same time, some indications were selling hand sanitizers with low quality are found in pharmacies and markets. "Business actors who violate the provisions as referred to in article 8, article 9, article 10, article 13 paragraph (2), article 15, article 17, paragraph (1) letter a, letter b, letter c, letter e, paragraph (2), and article 18 shall be sentenced to a maximum imprisonment of 5 (five) years or a maximum fine," according to Article 62 paragraph (1) of Law Number 8 of 1999 concerning Consumer Protection.

The criminal provisions above are appropriate to be given to business actors who commit acts of doubling prices and selling hand sanitizers of low quality. According to him, using Law Number 7 of 2014 concerning Trade Article 107, which explains that business actors are prohibited from raising prices when there is a shortage of goods to take action against business actors who commit such acts, is very inappropriate. Because the intended object is not an object regulated in the front and the hand sanitizer also does not have the highest retail price, there is no restriction on the selling price. Law enforcement in doubling the price of hand sanitizers cannot immediately take action that the act is a criminal act. According to the Head of the Investigation Unit, to assess something is based on an illegal act based on events in the field, victims, and applicable laws and regulations. Field events are actions that others can witness. The victim is the person who is harmed. Legislation is the basis for determining whether the act is a criminal act or not.

The conditions for a person to be convicted are that a person commits an act, his act is against the law, is dedicated in error, his actions are formulated in the law, and can be accounted for. Business actors who meet the above requirements will be dealt with following criminal provisions if they are proven to have committed acts of doubling the price of hand sanitizers knowingly and without coercion, wanting to make profits for themselves by harming other people, namely consumers. The crime is seen from his actions, namely actions that are considered despicable by the community and cannot be accepted by the habits that exist in society. Regardless of whether or not there is a legal basis that regulates the doubling of the price of hand sanitizer if the community feels aggrieved, then the act can be categorized as a criminal act. In this case, the police's task is to investigate business actors suspected of doing this so that they can immediately provide criminal sanctions to the perpetrators and provide a sense of security in the community.

Seeing that the actions were taken by business actors that double the price of hand sanitizers are detrimental to the community, business actors can be punished according to the applicable provisions, namely Law Number 7 of 2014 concerning Trade and Law Number 8 of 1999 concerning Consumer Protection. It is contained in Article 107 of Law Number 7 of 2014 concerning Trade and Article 62 paragraph (1) of Law Number 8 of 1999 concerning Consumer Protection.

"Business actors who store necessities and essential goods in a certain amount and time when there is a shortage of goods, price fluctuations, and barriers to Trade traffic in goods as referred to in Article 107 of Law Number 7 of 2014 concerning Trade, Article 29 paragraph (1) shall be sentenced to a maximum imprisonment of 5 (five) years and a maximum fine of Rp. 50,000,000,000.00 (fifty billion rupiah)," according to Article 107 of Law Number 7 of 2014 concerning Trade. Article 107 of Law Number 7 of 2014 concerning Trade describes criminal sanctions based on Article 29 paragraph (1) of Law Number 7 of 2014 concerning Trade, which explains several elements used as benchmarks in criminalizing business actors. 
There are 3 (three) elements in the article, namely scarcity of goods, price fluctuations, and hoarding of goods.

Of the three elements, the scarcity of goods occurs due to increasing people's purchasing power by buying hand sanitizers in large quantities during the COVID-19 disaster. Price fluctuations are caused by the increasing number of people who purchase hand sanitizers in large quantities, which results in the stock of hand sanitizers running out. Therefore business actors take the opportunity to increase prices that are not appropriate. Meanwhile, hoarding goods is an intentional act by business actors so that when the stock of hand sanitizers in some areas runs out, other business actors will look for hand sanitizers at business actors who commit fraud by selling hand sanitizers at more than the price sold by other business actors.

"Business actors who violate the provisions as referred to in article 8, article 9, article 10, article 13 paragraph (2), article 15, article 17, paragraph (1) letter a, letter b, letter c, letter e, paragraph (2), and article 18 shall be sentenced to a maximum imprisonment of 5 (five) years or a maximum fine of Rp. 2,000,000,000.00 (two billion rupiah)," according to Article 62 paragraph (1) of Law Number 8 of 1999 concerning Consumer Protection.

Article 62 paragraph (1) of Law Number 8 of 1999 concerning Consumer Protection explains the criminal sanctions based on Article 10 of Law Number 8 of 1999 concerning Consumer Protection which explains several elements that are the benchmark in criminalizing business actors. The article has five components: tariffs on goods prices uses of goods, conditions of goods, offers or discounts, and dangers of using goods. Two of the five elements serve as a benchmark for punishment in doubling the price and low quality in the manufacture of hand sanitizers. The two elements are the price of an item and the condition of an object. In this case, the cost of an article, hand sanitizer, has increased in price that is not following the previous price. The condition of an item, namely hand sanitizer that is sold, is of low quality due to its manufacture not being under applicable regulations.

Based on the 3 (three) interviews above, the author concludes that the crime of doubling the price of hand sanitizers can be punished with criminal sanctions as stated in Law Number 7 of 2014 concerning Trade Article 107 and Law Number 8 of 1999 concerning Consumer Protection Article 62 paragraph (1). If Law Number 7 of 2014 concerning Trade is constrained, the addressed object is not in the act. Given that the law aims to maintain public order and security, seeing the existence of the ius curia novit principle, all judges are considered to know the law so that the court may not refuse to examine and try a case even though the patient has no legal basis121. The principle of its curia novit is emphasized in Law Number 48 of 2009 concerning Judicial Power Article 10, which reads, "the court is prohibited from refusing to examine, try, and decide on a case that is submitted on the pretext that the law does not exist or is unclear, but is obliged to examine and judge him."

Based on this, the judge has the authority to determine which objective law must be applied, whether it comes from positive law or jurisprudence or based on custom. Looking at these provisions, it is inevitable that doubling the price of hand sanitizers can be subject to criminal sanctions provided that the judge has good intentions to consider that the act is a criminal act with consideration of jurisprudence and habits that exist in the community.

Jurisprudence is a judge's decision (judge-made law) followed by other judges in a similar case (similia similibus principle). The judge's decision becomes permanent so that it becomes a source of direction. Jurisprudence in practice functions to change, clarify, abolish, create, or confirm laws that have lived in society. The need for new legal rules to provide a sense of security in the community and realize the law aspired to. If the crime of doubling the price of hand sanitizer cannot be punished, then the same thing may happen under certain circumstances one day. 
There are several criminal acts of doubling the price of hand sanitizers that occur outside the City of Semarang. The author takes the example of a case in Semarang, Central Java province, under the jurisdiction of the Central Java Regional Police. The arrests of 3 (three) perpetrators with the initials A (45), N (24) years, and AU (45) were suspected of hoarding goods in the form of hand sanitizers and confiscating 208 bottles of antiseptic. The Head of Public Relations of the Central Java Regional Police explained how the perpetrators sold hand sanitizers and the prices listed as follows: "According to the information from the perpetrators that we have confirmed regarding the sale, they buy from people and then trade online, and the prices that have been traded are around Rp. . 270,000. up to Rp. 275,000 per box. If the market price is around 30 to 40 thousand, the normal price is per box."

The Director of General Criminal Investigation of the Central Java Regional Police, Kombes Pol. Budhi Haryanto added that the marketing carried out by the perpetrators was online, namely Facebook. It also includes a phone number on Facebook. From there, people who feel panicked finally look for items that are indeed rare in the market. Scarcity occurs in several areas of Central Java, starting from the north coast of Brebes to Kendal. For this reason, the Central Java Regional Police took decisive action to secure 3 (three) suspected perpetrators who are currently still being investigated. If proven, they will be subject to two articles, Law Number 7 concerning Trade and Law Number 8 of 1999 concerning Consumer Protection. punishable by 5 (five) years in prison. "The perpetrators are still under investigation by investigators to be able to determine whether the person concerned is guilty or not," said Combes Pol Budhi.

Following what the author has described, the crime of doubling the price of hand sanitizers can be punished by Law Number 7 of 2014 concerning Trade and Law Number 8 of 1999 concerning Consumer Protection. However, the punishment of a person cannot use two legal instruments at the same time, so a proper examination is needed to determine the legal basis based on the elements that exist in each law. The importance of the role of the police in handling these cases appropriately and quickly is to break the chain of crime so that there are no more crimes of doubling the price of hand sanitizers. Judging from the information from the Central Java Regional Police, Semarang City is included in an area where there is a shortage of goods, namely hand sanitizers. Therefore, there is a need for coordination between the Central Java Police and the Semarang City Police to crack down on existing crimes.

The President of the Republic of Indonesia has directed the Indonesian National Police to investigate the crime of increasing the price of hand sanitizers, resulting in stockpiling. The presidential order is the ideal legal basis for dismissing that hand sanitizer is not an essential item. The arrests made by the Central Java Regional Police for business actors who doubled the price of hand sanitizers directly impacted the average cost of hand sanitizers in Semarang City. And there is no longer a shortage of essential items, namely hand sanitizer.

\section{Conclusion}

In Indonesia's positive criminal law, the offence of doubling the price of hand sanitizer is governed by Law Number 7 of 2014 about Trade and Law Number 8 of 1999 concerned Consumer Protection. The results of research with 3 (three) related agencies that the implementation of criminal provisions regarding the crime of doubling the price of hand sanitizers is contained in Article 107 of Law Number 7 of 2014 concerning Trade and Article 62 paragraph (1) of Law Number 8 of 1999 concerning Consumer Protection. The formulation of the article contains the following elements: 1) In Article 107 of Law Number 7 of 2014, 
there are 3 (three) elements, namely scarcity of goods, price fluctuations, and hoarding of goods., 2) While in Article 62 paragraph (1) Law Number 8 of 1999 concerning Consumer Protection contains 2 (two) elements, namely the price of an item and the use of the item. Business actors who have doubled the price of hand sanitizers have proven to meet these elements.

\section{References}

[1] C. I. Burhanuddin and M. N. Abdi, "Ancaman Krisis Ekonomi Global Dari Dampak Penyebaran Virus Corona (COVID-19)," AkMen, vol. 17, no. April, pp. 90-98, 2020.

[2] D. Kurniawan, A. Sutan, I. Mufandi, E. Supriyanto, and M. Rachmawati, "Social Media Used to Spread Vaccination Program: Case of Indonesia Vaccination Covid-19 Policy,” 2021, doi: 10.4108/eai.6-3-2021.2306469.

[3] R. Listio and F. Santiago, "Analysis of the Role of Insurance Law of the Impact of the Covid-19 Pandemic for Indonesian Community Insurance,” 2021, doi: 10.4108/eai.6-32021.2306294.

[4] Y. Wulandari and F. Satiago, "The Use of Mediation to Resolve Dispute on Health Services as a Legal Protection for Nurse," 2021, doi: 10.4108/eai.6-3-2021.2306383.

[5] L. Agustino, "Analisis Kebijakan Penanganan Wabah Covid-19: Pengalaman Indonesia Analysis Of Covid-19 Outbreak Handling Policy: The Experience Of Indonesia," Junal Borneo Adm., vol. 16, no. 2, pp. 253-270, 2020.

[6] D. Tuwu, "Kebijakan Pemerintah Dalam Penanganan Pandemi Covid-19," J. Publicuho, vol. 3, no. 2, p. 267, 2020, doi: 10.35817/jpu.v3i2.12535.

[7] M. N. Sholikin and Herawati, "( Legal Aspects of Occupational Safety and Health for Medical and Health Workers During the Pandemic )," Maj. Huk. Nas., vol. 50, no. 2, pp. 1-20, 2020.

[8] Keppres No. 12 Tahun 2020 Tentang Penetapan Bencana Nonalam Penyebaran Corona Virus Disease 2019 Sebagai Bencana Nasional. .

[9] M. R. Apriansyah, "Analisis Penertapan Teori Pembalasan atau Absolut Pada Pidana Mati Kejahatan Narkotika Dalam Putusan Hakim Nomor: 651/PID.SUS/2015/PTMDN," Universitas Sriwijaya, 2016.

[10] M. Md, "Membangun Politik Hukum, Menegakkan Konstitusi," Pustaka LP3ES. Jakarta, 2006.

[11] S. Hartono, "Perspektif Politik Hukum Nasional: Sebuah Pemikiran," in Hukum dan Pembangunan, 1983, pp. 465-480. 